\title{
Chinese Concepts and Relational International Politics
}

\author{
Emilian Kavalski \\ Australian Catholic University
}

\begin{abstract}
The rise of China troubles the taken-for-granted epistemological and ontological constitution of International Relations (IR) theory. The Greek term 'theoria' implied travelling to foreign locales with the aim of gaining illumination that can then simultaneously inform and transform the 'home' of the traveler. Yet, instead of travelling, IR theory engages in silencing. This paper undertakes an interpretative journey of China's IR concepts. In particular, it looks at the notion of guanxi - one of the two terms that goes into the Chinese phrase for International Relations (guoji guanxi). The contention is that 'relationality' renders a more accurate translation of guanxi in English. In the process, the paper uncovers the practices of 'international relationality' as an opportunity to redefine the 'international' as a co-dependent space where two or more actors (despite their divergences) can interface into a dialogical community.
\end{abstract}

Keywords: Guanxi, relationality, post-Western International Relations, Chinese International Relations, relational International Relations

\section{Introduction}

How China thinks and in what ways its history and traditions inform the idiosyncrasies of China's international outlook have grown into a cottage industry both in IR and across the full spectrum of the humanities and social sciences. As Benjamin Schwartz presciently observed fifty years ago, the issue which always seems to stump China hands is whether “"the Chinese' [are] prepared to accept the nation-state system that governs the international life of the West or are their images of the world and of China's place in it still governed by cultural habits derived from the remote past"? ${ }^{1}$ On the one hand, such concern reflects IR's tendency to organize around the perceived experiences, interests, and concerns of powerful (Western) nation-states. ${ }^{2}$ On the other hand, at the heart of this query is China's positioning in European intellectual imagination as the ultimate Other or what Michel Foucault called heterotopia - a disturbing place, whose difference 'undermines language' ${ }^{3}$ China becomes 'the Other country' not merely because of its location on the opposite end of the Eurasian landmass, but also because it represents 'a culture entirely devoted to the ordering of space,

Emilian Kavalski, Associate Professor, Institute for Social Justice, Australian Catholic University. Email: Emilian.Kavalski@ acu.edu.au.

Benjamin I. Schwartz, “The Maoist Image of World Order,” Journal of International Affairs 21, no. 1 (1967): 92.

C. Chowdhry and S.M. Rai, "The Geographies of Exclusion and the Politics of Exclusion: Race-based Exclusions in the Teaching of International Relations,” International Studies Perspectives 10, no. 1 (2009): 85.

3 Michel Foucault, The Order of Things: An Archaeology of the Human Sciences (London: Routledge, 1973). 
but one that does not distribute the multiplicity of existing things into any of the categories that make it possible for us to name, speak, and think' ${ }^{4}$

In this setting, it should not be surprising that the recent promulgation of Chinese concepts into the ratiocination of IR not only questions "the very "constitutional structures" that are the core of the international system', ${ }^{5}$ but also calls on IR theory to embark on the road less travelled of encountering the multiverse of relations animating global life. It would therefore make sense to embark on this journey with a brief overview of the etymology of the term theory. In its Greek original, the term theoria meant 'a journey or a pilgrimage', involving a willingness to travel to foreign locales that can then simultaneously inform and transform the "home" of the traveller. ${ }^{6}$ Equally significantly, by providing a potent form of social interactions, the itinerant performativity of such theoretical travels seem to have played an important role in shaping international relations at the time by providing opportunities for 'constant reframing and reconfigurations of participants towards each other', which allowed the ancient Greeks to 'imagine and exploit forms of inter-polis contact'. ' By extension, theorizing becomes a relational process of irruptive translation that brings in dialogue the form and substance of the languages and experiences of diverse and infinitely complex worlds. ${ }^{8}$ Yet, instead of such itinerant translation, IR theory seems to recognize 'other' forms of theory-building only to the extent that they can be 'arranged according to the English idiom'.

The point here is that IR knowledge - just like any other knowledge - can neither pretend to be monological, nor does exist in isolation; rather to know one thing, IR scholars not only have to know and be curious about a lot of other things, but also be willing to engage them (and countenance others engaging) in imagining, questioning, advancing, and co-creating the range of "the plausible" practices and theories for their explanation and understanding. ${ }^{9}$ Such an endeavor should resonate with much of what the mainstream already admits theorizing in IR is about - namely, the identification, observation, explanation, and understanding of patterns by looking at the record of what happens when international actors come together in space and time. As it should become apparent, this article draws attention to the porousness and unpredictability of global life - both Western and non-Western - and the messy and contingent interactions that permeate and constitute both. This article affiliates itself with ongoing efforts to world IR. ${ }^{10}$ On the one hand, such endeavours intend to pluralize disciplinary inquiry by engaging previously excluded alternatives for thinking and doing world politics that have been forged both historically and in contemporary times by scholars, practitioners, and activists. On the other hand, such wording offers productive openings for

\footnotetext{
Foucault, The Order of Things, xix.

Allen Carlson, "Moving Beyond Sovereignty? A Brief Consideration of Recent Changes in China's Approach to International Order and the Emergence of the Tianxia Concept," Journal of Contemporary China 20, no. 68 (2010): 96.

6 Andrea Wilson Nightingale, Spectacles of Truth in Classical Greek Philosophy: Theoria in Its Cultural Context (Cambridge: Cambridge University Press, 2004), 4-9.

Barbara Kowalzig, "Performances of Theoria in Their Sacred and Political Context," in Pilgrimage in Graeco-Roman and Early Christian Antiquity, ed. Jas Elsner and Ian Rutherford (Oxford: Oxford University Press, 2005), 41-72.

Emilian Kavalski, "Timescapes of Security: Clocks, Clouds, and the Complexity of Security Governance," World Futures 65, no. 7 (2009): 527-51.

9 Romand Coles, Visionary Pragmatism (Durham, NC: Duke University Press, 2016), 63.

10 Amitav Acharya, "Ethnocentrism and Emanipatory IR Theory," in (Dis)Placing Security: Critical Re $\square$ evaluations of the Boundaries of Security Studies, ed. S. Arnold and J.M. Beier (Toronto, ON: Centre for International and Security Studies, 2000), 1-18; Ching-Chang Chen, "The Absence of Non-Western IR Theory in Asia Reconsidered," International Relations of the Asia-Pacific 11, no. 1 (2011): 1-23; Emilian Kavalski and Young Chul Cho, "Governing Uncertainty in Turbulent Times," Comparative Sociology 14, no. 3 (2015): 429-44; LH.M. Ling, The Dao of World Politics (London: Routledge, 2015); Kosuke Shimizu, "Materializing the Non-Western," Cambridge Review of International Affairs 28, no. 1 (2015): 3-20.
} 
bringing in conversation a wide range of cosmologies, power relations, and vulnerabilities than are typically accounted for by the narratives of IR. This article therefore intends an interpretative journey into the Chinese concepts and definitions of the international with the intention to explore whether they indeed are so heterotopic as to be unintelligible to IR.

At the centre of this investigation is the Chinese term guanxi (traditional: 關係 simplified: 关系). It has to be stated at the outset that the focus on guanxi is not entirely coincidental. It is one of the words that make up the term 'International Relations' in Chinese - guoji guanxi (traditional: 國際關係 simplified: 国际关系). In this respect, it should appear surprising that there has been so little attention in the literature on IR on the meaning and content of the terms that go into the making of the Chinese phrase for IR. The contention is that such disinterest illustrates the Eurocentric commitments of the discipline, which has consciously discouraged students of world politics to be "curious about the "non-West" but has encouraged them to explain away non-Western dynamics by superimposing Western categories'. ${ }^{11}$ What is particularly telling is that one does not have to be fluent in Chinese to encounter the complex texture of the term - for instance, the literatures on Business Administration, Organization Studies, Cross-Cultural Communication, Psychology and Sociology offer a huge repository of information about the meaning and practices of guanxi. This paper draws on these literatures to tease out the content and practices of this term, as well as its implications for IR theory and practice. The epistemic verso of the relational IR theory proposed by this article is that relationality is about the cultivation of attentiveness to the self-organizing, shifting, and historically and geographically contingent realities of the global life we inhabit.

The necessary caveat is that the paper focuses on the ideal type inherent in the guanxi model of relationality rather than the actual practices of Chinese foreign policy. While such connections are clearly there (especially, in places like Central Asia and in initiatives such as the "One Belt, One Road" policy), the point here is to draw attention to the epistemic and ontological relationality made possible by the encounter with guanxi. In other words, this is an article not about the international practices of China, but about the ways in which Chinese concepts - such as guanxi - can aid the 'uncovery' of alternative and, especially, relational modes of IR theorizing. The concluding section evokes these registers of worlding mutuality by elaborating the ways in which guanxi can help transcend the Western/non-Western bifurcation that dominates so much of the literatures both on relationality and IR theory. The claim of this article is that the defining feature of Western/Eurocentric IR is its lack of relationality. Conversely, what makes post-Western IR 'post-Western' is its responsiveness and receptivity of perspectives that are not one's own. It is with the intention to aid the disclosure of such ontological and epistemic relationality that this investigation enlists the Chinese concept of guanxi.

\section{Guanxi: What's in a Name?}

Guanxi appears to be one of those essentially contested concepts, whose meaning and practices are anything but clear cut and universally accepted. Therefore, most commentators tend to take as their point of departure the etymology of the two characters that make guanxi: 'guan means barriers and $x i$ means connections'. ${ }^{12}$ More specifically, guan designated a

${ }^{11}$ Pinar Bilgin, “Thinking Past Western IR,” Third World Quarterly 29, no. 1 (2008): 11; Emilian Kavalski, The Guanxi of Relational International Theory (London: Routlege, 2017).

12 Wenshan Jia, "The Wei (Positioning)-Ming (Naming)-Lianmian (Face)-Guanxi (Relationship)-Renqing (Humanized 
"“wooden crossbar for doors," "strategic pass," "toll gate" or the activity of "closing' or 'connecting', while $x i$ used to refer to 'tie' or to 'care for'. ${ }^{13}$ The literal meaning of guanxi then was 'connection across barriers' or 'pass the gate and get connected'. ${ }^{14}$ Metaphorically speaking however 'inside the door [or within the boundaries set by the barriers/toll gates] you may be "one of us," but outside the door your existence is barely recognized'. ${ }^{15}$ This inference should not be misunderstood as a suggestion of a rigidly-structured framework of exclusion. On the contrary, guanxi denotes openness to connections with other people and suggests a far more flexible and dynamic 'web of relationships that functions as the set of interlocking laces which connects people of different weis [positions/status]' ${ }^{16}$ It is also claimed that even though pragmatic, a guanxi relationship is profoundly infused with 'a higher sense of responsibility towards others' ${ }^{17}$

Guanxi is more often than not understood to denote the establishment and maintenance of 'an intricate and pervasive relational network' engendered by the practice of unlimited exchange of favours between its members and bound by reciprocal obligation, assurance, and mutuality. ${ }^{18}$ Yet, many have hinted that such practices reflect a far richer meaning of the term in Chinese than in its English counterpart 'relationship' - namely, 'guanxi refers to relationship in the most profound sense of the term'.${ }^{19}$ Owing to the dynamism of social interactions, 'the final word on guanxi can never be concluded' since the practices that it denotes are constantly evolving to adapt to the ever-changing contexts and patterns of global life. ${ }^{20}$ This fluidity has permeated the English-language literature on the topic through the multiple translations that the term has acquired - 'relations', 'connections', 'friendship', 'networks of reciprocal bonds', 'social capital', 'nepotism', and 'corruption'. While such multiplicity of meanings should not necessarily be surprising (after all, any translation can offer only a partial impression of the ideational context within which the term originates), it still suggests the layered and contingent framing in the Chinese original as well.

In this respect, there are a couple of puzzling features when it comes to the term guanxi. On the one hand, despite its indeterminacy guanxi occupies a central position in China's worldview. It has been labelled as 'the lifeblood of all things Chinese - business, politics, and society'. ${ }^{21}$ The grandee of China Studies, Lucien Pye referred to it as 'one of the most fundamental aspects of Chinese political behaviour', ${ }^{22}$ while the political philosopher

Feelings)-Complex in Contemporary Chinese Culture," in Confucian Cultures of Authority, ed. Peter H. Hershock and Roger T. Ames (Albany, NY: SUNY Press, 2006), 49-54; Yadong Luo, "Guanxi: Principles, Philosophies, and Implications," Human Systems Management 16, no. 1 (1997): 49; Don Y. Lee, and Philip L. Dawes, "Guanxi, Trust, and Long-Term Orientation in Chinese Business Markets," Journal of International Marketing 13, no. 2 (2005): 29.

13 Eike A. Langenberg, Guanxi and Business Strategy (New York: Springer, 2007), 5.

14 Jia, "The Wei (Positioning)," 49-54; Luo, "Guanxi," 49; Lee and Dawes, "Guanxi, Trust," 29.

15 Luo, "Guanxi," 44.

16 Kwang-kuo Hwang, "Face and Favour: The Chinese Power Game," American Journal of Sociology 92, no. 4 (1987): 963; Jia, "The Wei (Positioning)," 49-54.

17 Shijun Tong, "Chinese Thought and Dialogical Universalism," in Europe and Asia beyond East and West, ed. Gerard Delanty (London: Routledge, 2006), 309.

18 Luo, "Guanxi," 44; Jon P. Alston, "Wa, Guanxi, and Inhwa: Managerial Principles in Japan, China, and Korea," Business Horizons 32, no. 2 (1989): 28; Lucian W. Pye, Chinese Commercial Negotiating Style (Cambridge, MA: Oelgeschlager, Guun, and Hain, 1982), 882.

19 Duran Bell, “Guanxi: A Nesting of Groups," Current Anthropology 41, no. 1 (2000): 133.

20 Mayfair Mei-hui Yang, "The Resilience of Guanxi and Its New Deployments: A Critique of Sone New Guanxi Scholarship," The China Quarterly 42, no. 170 (2002): 459.

21 Luo, "Guanxi,"45.

22 Lucian W. Pye, "Factions and the Politics of Guanxi: Paradoxes in Chinese Administrative and Political Behaviour," The 
Wenshan $\mathrm{Jia}^{23}$ claims that guanxi is one of the central philosophical concept that 'reflects the Chinese way to know about reality (ontology), the Chinese way to interpret reality (phenomenology), and the Chinese values about humanity (axiology)'. On the other hand, guanxi's significance appears to be of a very recent provenance. While in circulation a century ago, the term was not deemed to be significant enough to warrant inclusion in the two classic Chinese dictionaries - the 1915 ci yuan ('sources of words') and the $1936 \mathrm{ci}$ hai ('word sea'). ${ }^{24}$ In this respect, guanxi's rise to prominence is closely associated with social, political, and economic processes set in motion during the second half of the twentieth century. Some have even speculated whether there is anything particularly Chinese about guanxi or whether it is merely the Chinese stand-in for the general social phenomenon of reliance on favours to accomplish tasks. ${ }^{25}$ It is also noteworthy that such rearticulation of the term and practices of guanxi was occurring simultaneously across the expanse of the 'Chinese commonwealth'26 in mainland China, Taiwan, Hong Kong, Macau, and Singapore, as well as the Sinophonic diaspora around the globe.

Commentators have noted that the practices of guanxi have acquired positive and negative connotations both of which seem to arise from its propensity for subversion of state structures. In the case of the former, guanxi assists with bottom-up and civil society empowerment by permitting 'individuals to use their social ingenuity to build a web of personal relationships' ${ }^{27}$ A number of commentators find the origins of this trend during the Maoist years in China, when guanxi networks provided ordinary people with opportunities to distance themselves from the oppressive state-saturated system, carve out room to manoeuvre, and order their own lives. ${ }^{28}$ Thus, by engaging in alternative forms of solidarity, the relational power of guanxi allows those in asymmetrical relationships to subvert established hierarchies and to mitigate the dilemmas of over-regulation and the political pressures imposed on everyday life.

The negative flavour of guanxi comes from its association with graft. In this respect, the very patterns that make guanxi a "weapon of the weak'29 are also the key ingredients of its dark side. Yet, rather than essentializing it as a cultural trait associated with Asian backwardness, this aspect of guanxi can be read as an idiosyncratic encounter between the forces of transnational capitalism and the economic development of the state. ${ }^{30}$ As the late Lee Kuan Yew, the founding father of modern Singapore, has acknowledged, the Chinese use guanxi 'to make up for the lack of rule of law and transparency in rules and regulation'. ${ }^{31}$ In this setting, phrases such as 'crony capitalism' and 'Confucian nepotism' seem to overlook the socio-temporal contingency underpinning the bounds of obligation and networks of

\footnotetext{
23 Jia, "The Wei (Positioning)," 49-54.

24 Luo, "Guanxi," 44; Langenberg, Guanxi, 4.

25 Thomas Gold, Dong Ghine, and David L. Wank, Social Connections in China: Institutions, Culture, and the Nature of Guanxi (Cambridge: Cambridge University Press, 2002), 13-4; Alena Ledeneva, “'Blat' and 'Guanxi': Informal Practices in Russia and China," Comparative Studies in Society and History 50, no. 1 (2008): 124.

26 Irene Y.M. Yeung and Rosalie L. Tung, "Achieving Success in Confucian Societies: The Importance of Guanxi (Connections)," Organizational Dynamics 25, no. 2 (1996): 58.

27 Anne S. Tsui and Jiing-Lih Larry Farh, "Where Guanxi Matters: Relational Demography and Guanxi in the Chinese Context," Work and Occupations 24, no. 1 (1997): 60

28 Yang, "The Resilience," 466.

29 Ledeneva, “'Blat',"124; Mayfair Mei-hui Yang, Gifts, Favors, and Banquets: The Art of Social Relationships in China (Ithaca, NY: Cornell University Press, 1994), 206.

${ }^{30}$ Yang, "The Resilience," 468.

31 Cited in Yeung and Tung, "Achieving Success," 56.
} 
support that characterize the practices of guanxi. ${ }^{32}$ In fact, some have gone as far as to claim that what (Western) observers usually criticize as the corrupt side of guanxi is in fact the misunderstood 'Confucian Ethic' of Asian capitalism. ${ }^{33}$

As the above discussion demonstrates, both the positive and negative features of guanxi reflect an idiosyncratic coalescence between tradition and modernity - or what some have referred to as the 'critical inheritance and critical transformation of Chinese thought' ${ }^{34}$ - in the process of achieving collective goals. In particular, guanxi reflects a commitment to act in accordance with social demands and expectations. As the eminent Chinese scholar Liang Shiming has pointed out, the Chinese worldview is 'neither geren benwei (individualbased) nor shehui benwei (society-based), but guanxi benwei (relation-based)'. ${ }^{35}$ The emphasis on relationality infers a different way of being present in the world. In Chinese scholarship such difference pivots on the contrast between relational and autonomous self. Associated with Western intellectual traditions, the latter insists on discrete subjectivities, praises individualism, and values and normalizes the lack of dependence on others. The relational self, on the other hand, insists that individuals do not and cannot exist unless they are enmeshed in relations with others. It seems that the origins of this conceptualization can be traced back to Confucius, himself, for whom 'unless there are at least two human beings there are no human beings' ${ }^{36}$ The relational self, thereby, is 'one which is intensely aware of the social presence of other human beings' ${ }^{37}$

A central feature of this intersubjective identification is the claim that 'the self so conceived is not a static structure but a dynamic process. It is a center of relationships, not an enclosed world of private thoughts and feelings. It needs to reach out, to be in touch with other selves, and to communicate through an ever-expanding network of human relatedness' ${ }^{38}$ The interdependence and reciprocity characterizing such relational self, accords social relations much greater significance and relations are often seen as ends in and of themselves rather than means for realizing various individual goals. ${ }^{39}$ The key inference is that participants in a guanxi perceive each other to be 'role occupants rather than individuals' ${ }^{40}$ Concurring with Chih-yu Shih's proposition, ${ }^{41}$ the claim of this study is that the relationality of guanxi is focused on the management of hostile role-playing in order to maintain the longevity of interactions. In particular, the proposition here is that role-demands do not emerge in the abstract, but are borne out of the process of interactions. Since roles are circumstantial, the qualitative innovation emerging from the dynamics of guanxi is that an actor can play any role on the world stage regardless of their identity.

The emphasis on relationality is premised on a holistic worldview distinct from the

32 Yang, "The Resilience," 469-76.

33 Luo, "Guanxi,"48.

34 Qing Liu, "From 'All Under Heaven' to Critical Cosmopolitanism: The Transfromation of China's World Consciousness," in Shared Values in a World of Cultural Pluralism, ed. Candido Mendes (Rio de Janeiro: Academy of Latinity), 330.

35 Gold, Ghine, and Wank, Social Connections, 10.

36 Henry Rosemont, "Two Loci of Authority: Autonomous Individuals and Related Persons," in Confucian Cultures of Authority, ed. P.H. Hershock and R.T. Ames (Albany, NY: SUNY Press, 2006), 11-7.

37 Y.F. David Ho, "Selfhood and Identity in Cinfucanism, Taoism, Buddhism, and Hinduism: Contrasts with the West," Journal of the Theory of Social Behaviour 25 (1995): 117.

38 Wei-Ming Tu, Confucian Thought: Selfhood as Creative Transformation (Albany: SUNY Press, 1985), 133.

39 Tsui and Farh, "Where Guanxi Matters," 61; Larry Farh, Jiing-Lih, Anne S. Tsui, Katherine Xin and Bor-Shiuan Cheng, "The Influence of Relational Demography and Guanxi: The Chinese Case," Organization Science 9 (1998): 473.

40 Hwang, "Face and Favour," 945.

${ }^{41}$ Chih-yu Shih, "Transcending Hegemonic International Relations Theorization: Nothingness, Re-Worlding, and Balance of 
Western dualistic opposition between self and other/ self and the world. ${ }^{42}$ The 'focus is not fixed on any particular individual, but on the particular nature of the relations between individuals who interact with each other' ${ }^{43}$ Such construction of the relational self reveals the 'Chinese worldview as an integrated system of subject and object: the individual is placed in the spatial-temporal location of the world, with her experiences, values, and expectations constantly shaping and being shaped by the world'. ${ }^{44}$ In this setting, it is the guanxi process itself (rather than the individuals involved) that has agency - namely, it is "the "relation that selects," meaning that relations shape an actor's identity and influence her behaviour'. ${ }^{45}$ Lucian Pye ${ }^{46}$ sees in this dynamic the origins of the Chinese 'compulsive need to avoid disorder and confusion, to seek predictability and the comforts of dependency [which] makes them very anxious to seek any acceptable basis for orderly human relations'.

Owing to the fluidity of the way in which these relational roles are lived, guanxi asserts that change rather than stability is an endemic feature of global life. Both through attrition or accretion and depending on the circumstances, issues, and situations, the guanxi relationship has diverse and contingent iterations. Such dynamic multiplicity of interdependent conditioning factors engenders an interpersonal realm whose complexity is only partially known to the participating actors. ${ }^{47}$ This calls for a contextual attunement to the transient constellations of factors that impact on the content and trajectories of a relationship. Thus, the long-term orientation of guanxi inserts a modicum of predictability by lowering the transaction costs. At the same time, it can be used for multiple and diverse purposes, it builds resilience in the context of recognizing and influencing emergent opportunities. ${ }^{48}$

\section{What Can We Guanxi about in IR?}

How would IR look like if we were to imagine it from the point of view of guanxi? To begin with the outline of such an endeavour should not appear particularly outlandish (let alone heterotopic) to those attuned to the inescapable condition of mutual encounter defining global life. ${ }^{49}$ In particular, the relational pattern envisaged by the guanxi perspective supports the efforts to articulate most issues plaguing IR as 'communication problems'. ${ }^{50}$ The critical contribution of guanxi to these conversations is that IR is not merely an outcome of communicative actions (or a solution to communicative problems), but reflects the willingness of actors to expose themselves to the fluidity of ongoing relations with others. In particular, it suggests that the complex patterns of global life resonate with relationality and dynamism, rather than the static and spatial arrangements implicit in the self-other/centreperiphery models. ${ }^{51}$

\footnotetext{
${ }^{42}$ Qin Yaqing, "Why Is There No Chinese International Theory," International Relations of the Asia-Pacific 7, no 3 (2007): 310.

${ }^{43}$ Ambrose Y.C. King, "The Individual and Group Confucianism: A Relational Perspective," in Individualism and Holism: Studies in Confucian and Taoist Values, ed. Donald J. Munro (Ann Arbor,MI: University of Michigan Press, 1985), 63.

44 Jee Loo Liu, "Reconstructing Chinese metaphysics: A White Paper," Journal of East-West Thought 1, no. 2 (2011): 4.

45 Yaqing Qin, "Relationality and Processual Construction: Bringing Chinese Ideas into Inernational Relations Theory," Social Sciences in China 30 (2009): 9.

${ }^{46}$ Lucian W. Pye, The Spirit of Chinese Politics: A Psychocultural Study of the Authority Crisis in Political Development (Cambridge, MA: MIT Press, 1968), 174.

47 Hui-Ching Chang and G. Richard Holt, "The Concept of Yuan and Chinese Interpersonal Relationships," in Cross-Cultural Interpersonal Communication, ed. Stella Ting-Toomey and Felipe Corzenny (London: Sage, 1991), 34.

${ }^{48}$ Emilian Kavalski, Central Asia and the Rise of Normative Powers: Contextualizing the Security Governance of the European Union, China and India (New York: Bloomsbury, 2012), 74; and Pye, "Factions and the Politics of Guanxi," 44.

49 Liu, "From 'All Under Heaven'," 130.

50 Thomas Risse, "Let's Argue: Communicative Action in World Politics," International Organization 54 (2000): 1-39.

51 Emilian Kavalski, World Politics at the Edge of Chaos: Reflections on Complexity and Global Life (Albany, NY: State
} 


\subsection{Guanxi's harmonius respect for the other}

The focus on guanxi brings out that the basic ontological condition of international actors is relational - namely, the content of their existence as actors is constituted inter-subjectively during the very process of interaction. ${ }^{52}$ Thus, owing to prior conditions of relationality, an 'international' world of holistically structured meaning appears in the first place. A key feature of the guanxi outlook the relational world that it sustains is the emphasis on harmony. The discussion of the Chinese concept of harmony has attracted significant attention in recent years. What is important for the purposes of the current investigation is that these discussions of harmony draw attention to 'respect for the other' as the 'cardinal value' of China's strategic outlook. ${ }^{53}$ Such respect for the other articulates relationality through webs of 'non-wilful [and non-domineering] actions directed to realizing the potential events and others, and is action that animates others to act on their own behalf'.$^{54}$ The mutually benevolent relationships adumbrated by such harmonious encounters advance relational agency as a dialogical process, whose effects involve the efforts of all sides of the exchange. ${ }^{55}$ The point here is that guanxi ties are volitional (and not forced upon the participants) - actors intentionally commit to the interaction. It is for this reason that guanxi relations are characterized by dedicated cultivation. ${ }^{56}$ Such guanxi dynamics can be seen at work in China's 'policy of "pre-emptive participation" 57 in relations with a wide range of other international actors not only as a reassurance strategy aimed at allaying their concerns, but primarily as an effort to foster ongoing interactions with them.

Agency - especially, international agency - in such a relational setting is not about the intentional projection of self-interest, but about strategic receptivity - i.e., 'knowing oneself insofar as one is related to others, and knowing others insofar as others are related to oneself' ${ }^{58}$ Such reconfiguration of agency engenders ethical obligations to strive for harmony among and between the actors involved in the transaction..$^{59}$ Guanxi, thereby, presages an understanding of international action and agency - both cognitively and affectively - as simultaneously shaped and mediated by ethical obligations and commitments to others (the structure and content of which is acquired through the very relationships by which ethical obligations and commitments to others are disclosed).

The currency of such relationality is not legitimacy, but reputation. The cultivation of reputation (or what IR observers tend to refer as status) is the main aim of the harmonious respect for the other. As Jack Barbalet cogently observes, reputational standing is a social and not an economic resource. Thus, guanxi is deployed not with the aim to gain access

\footnotetext{
University of New York Press, 2015).

52 Emilian Kavalski, "The Struggle for Recognition of Normative Powers: Normative Power Europe and normative Power China in Context," Cooperation and Conflict 48 (2013): 247-67.

53 Brantly Womack, "China as a Normative Foreign Policy Actor," in Who is a Normative Foreign Policy Actor? (Brussels: Center for European Policy Studies), 294-7.

${ }_{54}$ Jack Barbalet, "Market Relations as wuwei: Traditional Concepts in the Analysis of China's Post-1978 Economy," Asian Studies Review 35, no. 3 (2011), 342-347; Kavalski, The Guanxi of Relational International Theory, 87.

${ }_{55}$ This challenge to the centrality of hegemonic monologues in the mainstream seems to resonate the inferences of the literature on communitarian IR.

56 Jack Barbalet, "Guanxi, Tie Strength, and Network Attributes," American Behavioural Scientist 59, no. 8 (2015): 1042.

${ }^{57}$ Jeremy Paltiel, "China's Regionalization Policies: Illieral Internationalism or Neo-Mencian Benevolence," in Emilian Kavalski, ed., China and the Global Politics of Regionalization (Abingdon: Routledge, 2009), 49.

${ }_{58}$ Wen Haiming and Wang Hang, "Confucian Cultural Psychology and Its Contextually Creative Intentionality," Culture \& Psychology 19, no. 2 (2013): 192.

59 Yu Bin, "China and Russia: Normalizing Their Relationship," in Power Shift: China and Asia's New Dynamics, ed. David 
to economic or political resources, but is 'primarily directed to acquiring and expending social resources' ${ }^{60}$ Not only that, but such understanding of relationality demands that those engaged in interactions are "more aware of the relationships that constitute the objects of their concern than they are of their own interests'. ${ }^{61}$

It is in this setting that xinyong (trustworthiness) - the reputation for meetings one obligations to others- gains its significance as 'the most valuable asset' in the transactional web of guanxi. ${ }^{62}$ Thus, rather than facilitating the legitimacy of one's actions, the strategic aim of guanxi is to enhance the trustworthiness of actors by providing series of situations in which they can continuously enact (as well as be evaluated on) their 'meeting the expectations of others' ${ }^{63}$ China's harmonious respect for the other is nothing short of a strategic desire for status recognition. ${ }^{64}$ Motivated by the status insecurity associated with the relational constitution of international interactions, the operational beliefs of guanxi provide ongoing modalities for engendering trust by demonstrating China's capacity and willingness to meet its obligations to others.

\subsection{Guanxi's logic of relationships}

Guanxi implies both a propensity and a capacity for living with and in ambiguity. In this respect, it provides a 'relational' (as opposed to 'rule-based') framework for the meaningful contextualization in the shifting patterns of global life. ${ }^{65}$ Thus, it is relations that are not only at the heart of explaining and understanding the world, but also central to its observation and encounter. As Qin Yaqing ${ }^{66}$ demonstrates, this understanding reframes power away from its association with the material possession of capacities for influence (regardless of whether they are coercive or not), but as a 'relational practice'. On the one hand, relations (and the webs of interactions that they constitute) provide a platform for the exercise of power. On the other hand, relations themselves have power - namely, they frame future patterns of interaction. ${ }^{67}$

This then becomes the centrepiece for the 'logic of relationships' animating global life. ${ }^{68}$ Such logic

assumes that while the future is unknown, the partners in the future are the same as in the past and present. Therefore, the significance of any specific interaction lies in how it shapes a particular relationship... The bottom line in a relationship logic is that both sides feel that they are better off if the relationship continues - this is the minimum meaning of 'mutual benefit'. A normal relationship does not require symmetry of partners or equality of exchanges, but it does require reciprocity [i.e., respect for the other]. ${ }^{69}$

It should be stated at the outset that such framing should not be misunderstood as an indication of an altruistic outlook on global life, but as an effective strategy for managing a hyper-social

60 Barbalet, "Guanxi," 1044.

61 Barbalet, "Market Relations," 346.

62 Donald R. DeGlopper, Commerce and Community in a Chinese City (Albany, NY: SUNY Press, 1995), $205-06$.

63 David Y.F. Ho, "On the Concept of Face," American Journal of Sociology 81 (1976): 873.

64 Kavalski, "The Struggle for Recognition".

65 Yaqing Qin, "Rule, Rules, and Relations: Towards a Synthetic Approach to Governance," Chinese Journal of International Politics 3, no. 2 (2011): 129-53; Emilian Kavalski, "Whether Power Transition and Whither If One," in Power Transition in Asia, ed. David Walton and Emilian Kavalski (London: Routledge, 2017), 207-21.

${ }^{66}$ Qin, "Rationality and Processual Construction".

67 Qin, "Rationality and Processual Construction," 9.

68 Kavalski, "The Struggle for Recognition".

69 Womack, "China as a Normative Foreign Policy Actor," 295-7. 
environment. The logic of relationships therefore outlines a 'context for action' in which goals can be achieved through an active, committed, and responsible involvement in world affairs. $^{70}$ Informed by the extremely situational and particularistic nature of Chinese culture, the logic of relationships infers that as the circumstances of interactions change, so too will the patterns of guanxi. ${ }^{71}$ Such framing also undermines the linear causality backstopping Western takes on relationality - namely, that if two (or more actors) interact with one another their relations will necessarily lead to greater intimacy. ${ }^{72}$

Rather than focusing on the personality or identity of participating actors, the logic of relationships suggests that the conditions for interaction 'cannot be forced' and remain 'largely unknown and unknowable. ${ }^{73}$ Thus, the process of interaction facilitates the likelihood of future relations (which is the key strategic function of guanxi) rather than intimacy. ${ }^{74}$ This demands both contextual sensitivity and an ongoing commitment to the deliberate practices of relationality. What is crucial about such logic of relationships is that as the hub of social knowledge and social life, the patterns of guanxi intimate that shared understandings are not imposed as rules, rights, or obligations, but emerge in the process of interaction.

Such framing informs the formulation of external relations. Owing to the contextual ubiquity of guanxi, foreign policy making becomes a contingent outcome of relational interactions between actors - that is, the relational context frames the policy response, but because of its inherent fluidity, policy is expected to fluctuate. ${ }^{75}$ In an interesting move, some commentators have inferred the 'logic of relationships' through Beijing's practice of 'third culture building to improve international relations'. ${ }^{76}$ The proposition is that guanxi can beget a 'third culture' through the practices of deliberate and repeated interactions, which brings together elements of the cultures of the interacting actors as well as new ones which emerge in the process of doing things together. It is this dynamism that informs the 'deeply relational' character of Chinese foreign policy. ${ }^{77}$ Rather than impeding the policy process, such contextual-attunement of the logic of relationships suggest the unexpected opportunities made possible by the 'third culture' of guanxi - for instance, the unintended evolution of the Shanghai-5 into the One Belt One Road initiative via the Shanghai Cooperation Organization. ${ }^{78}$

\subsection{Guanxi's community of practice}

It is communities of practice that locate the 'third culture' engendered by guanxi's logic of relationships. The inference here is that international agency emerges in a community not

\footnotetext{
70 Roberto Russell and Juan Gabrial Tokatlian, "From Antagonistic Autonomy to Relational Autonomy: A Theoretical Reflection from the Southern Cone," Latin American Politics and Society 45 (2003): 17.

71 Pye, "Factions and the Politics of Quanxi," 46.

72 Malcolm R. Parks, "Ideology of Interpersonal Communication: Off the Couch and Into the New World," in Communication Yearbook, ed. Michael Burgon (New Brunswick, NJ: Transaction Publishers, 1982), 79-107.

73 Chang and Holt, "The Concept of Yuan," 54.

${ }_{74}$ This should not however be misunderstood as an assertion that the process is not affective. The point here is that guanxi is not about the subjective qualities of the participants, but about the process of interactions that they enact.

${ }^{75}$ Feng Zhang, "Confucian Foreign Policy Traditions in Chinese History," The Chinese Journal of International Politics 8 (2015): 211

76 Jia, "The Wei (Positioning)".

77 Wenshan Jia, “An Intercultural Communication Model of International Relations: The Case of China," in Challenges to Chinese Foreign Policy: Diplomacy, Globalization and the Next World Power, ed. Yufan Hao, C.X. George Wei and Lowell Dittmer (Lexington, KY: University Press of Kentucky, 2009), 322-25.

${ }^{78}$ Emilian Kavalski, "Shanghaied into Cooperation: Framing China's Socialization of Central Asia," Journal of Asian and African Studies 45, no. 2 (2010): 131-45; Emilian Kavalski, "More of the Same: An Unpredictable Trump Foreign Policy in an Unpredictable Central Asia," Monde Chinois 4, no. 48 (2016): 112-17.
} 
in a vacuum. As suggested, it is the relational (rather than the rule-based) nature of guanxi that backstop the dialogical outcomes of its effects. In particular, it is guanxi's commitment to deliberate and unconditional sociality that motivates shared meaning-generation. The suggestion thereby is that while strategic, the relationality of guanxi is not motivated by selfinterest (i.e., it is not an instrumental means to an end). Instead, the driving force appears to be a commitment to the practice of doing things together - an aspect that can explain China's general aversion to formal institutional arrangements and the imposition of conditionality on its partners.

Such relationality is not zero-sum - i.e., 'the debit and credit sides of this [relational] balance sheet are never in equilibrium' - because this would spell the end of guanxi $i^{79} .{ }^{80}$ The accent is on the strategic value of maintaining the relationship. In fact, it is through the practice of doing things together that the normative and the ideational structure of global life gets engendered. ${ }^{81}$ The focus on guanxi suggests that by cherishing the chance of interactions (rather than force/work on a relationship), the Chinese outlook is predisposed to allow for contingency to take its course. ${ }^{82}$ In this respect, the interactive dynamics of communities of practice stimulate new and contextual definitions of the 'common good'. As Xi Jinping, the Chinese president, has himself hinted such 'inclusive relationalism' is founded on the affective feeling (ganqing) produced by the process of repeated interactions. ${ }^{83}$ Moreover, in such a dialogical context the possibility for constructing 'new histories' emerges by altering the suspicion and bias from past interactions and opening up opportunities for new avenues for interaction. ${ }^{84}$ Guanxi therefore spells a longer term horizon for relations than the short term gains espoused by mainstream IR. In this process, communities of practice reveal a new way of being present in the world through the binding power of deliberate interactions.

\section{In Lieu of a Conclusion: What is 'Post-Western' about Post-Western IR?}

This paper has demonstrated that the promise of a relational mode of IR inquiry is considerable. In this respect, the concept of guanxi shifts IR thinking away from a focus on international relations to one premised on global relationality. Thus, rather than looking at dyadic sets of relations as well as the identities and capacity of individual actors, guanxi inheres an IR as webs of figurations intertwined by a conscious and strategic search for relations with others. In this respect, actors (and their agency) have effects only to the extent that they are in relations with others. Thus, owing to the dynamic nature of such interactions, what passes for world order is not only constantly changing, but demands ongoing commitment to participating in and maintaining these relations. ${ }^{85}$

In this respect, the claim here is that the relational turn has become a defining feature of the so-called post-Western IR theory. It seems few today would dispute that the disciplinary

\footnotetext{
79 Yeung and Tung, "Achieving Success," 55.

80 At the same time, the value of the personal favour rendered in the context of guanxi (called renqing in Chinese) "can never be calculated objectively' - instead, its assessment is subject to an ongoing and complex 'blend of cost and quality and relationship in which one or two elements may be interpreted, by some people at certain times, as being more valuable than the other element(s)' (Hwang, "Face and Favour," 963).

81 Kavalski, "The Struggle for Recognition".

82 Chang and Holt, "The Concept of Yuan," 54.

83 Zhang, "Confucian Foreign Policy," 216.

${ }^{84}$ Qin, "Rule, Rules, and Relations," 129-53

85 It has to be acknowledged that the relationality lens has important bearing on current discussions of the content and practices of normative power in global life. In particular, it suggests that what distinguishes normative powers from soft powers is their relationality. See Kavalski, "The Struggle for Recognition"; Kavalski, Central Asia.
} 
inquiry of International Relations (IR) is indelibly marked by the 'colonial signs' of its Eurocentric makeup. Not only that, but the 'apple pie' flavour that IR acquired in the context of its Cold War transformation into an 'American social science' seems to have made the discipline even more inimical towards encounters with the various non-Western others that its outlook consciously occludes. In an attempt to trouble the juxtapositions of temporal and geographical difference that still seem to stump any IR alternative prefixed by a 'non-' or a 'post-', this paper emphasizes the centrality of relationality as a distinguishing feature of all such projects. Critical/post-colonial/non-Western IR narratives seem to have difficulty to obviate the theoretical slippage as a result of which 'the East' is unquestionably equated with 'Asia' and is then assumed to be part of the so-called 'Rest' and 'non-West'. Equally problematically, 'Eurocentrism' is invariably taken as a stand-in for 'West-centrism', 'Sinocentrism' for 'Chinese hegemony', and 'post' for 'anti'. In this setting, the relationality lens helps outline the contested terrain of post-Western IR as a space for dialogical learning, which promises a world that is less hegemonic, more democratic, international, and equitable.

In particular, such approach allows to build solidarity between like-minded projects targeting the silencing, hegemony, patriarchy, and violence of the mainstream by treating them as second-order aspects deriving from a first-order problematique - IR's poignant ontological and epistemic lack of relationality. It is the very denial of relationality (first order issue) that perpetuates the imperial, patriarchal, and racist attitudes (second order issues) of IR. It is in this vein that the attack on latter that so much of critical, feminist, and postcolonial theorizing undertakes, overlooks the very condition of its possibility - the lack of relationality in IR. What this means is that the IR mainstream has been dominated by an atomistic understanding of global life which prioritises fixed units of analysis (nation states) and their discrete dyadic interactions (conflict/balancing in the context of anarchy). Yet, at no point is the option of a sociability infused with the contingent opportunities inherent in the encounter with the other acknowledged in this narrative; let alone the potential that the phenomena and processes animating world affairs are mutually co-constituted in relation to one another. Instead, global life is envisioned as a domain of disconnected states, infamously imagined as billiard balls - 'closed, impermeable, and sovereign unit[s], completely separated from all other states' ${ }^{86}$

A relational IR - which is post-Western in the sense that it does not treat the West and the non-West as discrete and disconnected homogenous opposites, but intertwined and mutually constitutive webs of interactions - proposes a molecular outlook whose unit of analysis is relations (rather than actors) and their multiple triadic dynamics (which open numerous and numinous points of and possibilities for interaction). In other words, what makes post-Western IR narratives 'post-Western' is their emphasis on relationality - namely, things in global life are not merely interconnected, but that they gain meaning and significance within complex webs of entanglements and encounters with others. ${ }^{87}$ The emphasis on relationality thereby acts as a reminder that IR knowledge, just like any knowledge, is acquired and mediated relationally through diverse sets of practices. IR's denial of ontological relationality has its epistemic effects - perhaps, most perniciously evidenced by the imposition of a cannon reproduced around the world so that students can contribute to 'core' debates, while the

${ }^{86}$ Arnold Wolfers, Discord and Collaboration (Baltimore, NJ: The John Hopkins University Press, 1962), 19.

${ }_{87}$ The paper can thereby be read as a prolegomenon to a genuinely relational IR thinking and practice - one whose attention is not on reifying the bulwarks of national sovereignty and quantifying the national interest, but rather draws attention to the porousness and unpredictability of global life - Western and non-Western (and the messy and contingent intersections that permeate and constitute both). 
inputs of the 'periphery' are occluded from the 'Anglosphere' of Western IR journals and academia. ${ }^{88}$ Some have labeled this lack of epistemic relationality as IR's 'castle syndrome' rather than engagement with the multiverse of global life, proponents of different IR schools engage in defending and reinforcing the bulwarks of their analytical castles, while bombarding the claims of everybody else. ${ }^{89}$ Others have termed it as 'returnism' - IR's predilection for traditional conceptual signposts that provide intellectual comfort zones, disconnected from current realities..$^{90}$

The claim here is that both of these are instances of IR's unrelationality - knowledge does not exist in isolation; it is not built up atomistically and discretely from scratch; rather to know one thing, you have to know a lot of other things. A post-Western IR acts simultaneously as a reminder about the multiversal world we inhabit and the composite nature of IR's episteme. Such relational IR theorizing is cultivated from the convivial, yet dissonant cross-pollination of values, narratives, and practices in the study of world affairs. At the same time, it is this very receptivity of a relational IR that holds the promise for working about and working with the 'edges of radical unusual possibilities'. ${ }^{11}$ Thus, engaging with and listening curiously and provocatively to the phenomenon of guanxi invokes the complexity of possible worlds uncovered by relational IR theorizing.

\section{Bibliography}

Acharya, Amitav. "Ethnocentrism and Emanipatory IR Theory." In (Dis)Placing Security: Critical Re-evaluations of the Boundaries of Security Studies, edited by S. Arnold and J.M. Beier, 1-18. Toronto, ON: Centre for International and Security Studies, 2000.

Alston, Jon P. “Wa, Guanxi, and Inhwa: Managerial Principles in Japan, China, and Korea.” Business Horizons 32, no. 2 (1989): 26-31

Avelino, Flor, and Jan Rotmans. "Power in Transition: An Interdisciplinary Frameowrk to Study Power in Relation to Structural Change." European Journal of Social Theory 12, no. 4 (2009): 543-69.

Barbalet, Jack. "Guanxi, Tie Strength, and Network Attributes." American Behavioural Scientist 59, no. 8 (2015): 1038-50.

_ . "Market Relations as wuwei: Traditional Concepts in the Analysis of China's Post-1978 Economy." Asian Studies Review 35, no. 3 (2011): 335-54.

Barkin, J. Samuel. Realist Constructivism: Rethinking International Relations Theory (Cambridge: Cambridge University Press, 2010).

Bell, Duran. "Guanxi: A Nesting of Groups.” Current Anthropology 41, no. 1 (2000): 132-8.

Bilgin, Pinar. “Thinking Past Western IR.” Third World Quarterly 29, no. 1 (2008): 5-23.

Bin, Yu. "China and Russia: Normalizing Their Relationship." In Power Shift: China and Asia's New Dynamics, edited by David Shambaugh, 228-47. Berkeley, CA: University of California Press, 2005.

Carlson, Allen. "Moving Beyond Sovereignty? A Brief Consideration of Recent Changes in China's Approach to International Order and the Emergence of the Tianxia Concept.” Journal of Contemporary China 20, no. 68 (2010): 89-102.

Chang, Hui-Ching, and G. Richard Holt. “The Concept of Yuan and Chinese Interpersonal Relationships.” In Cross-

${ }_{88}$ Srdjan Vucetic, The Anglosphere: A Genealogy of Racialized Identity in International Relations (Stanford, CA: Stanford University Press, 2011); Emilian Kavalski, "Recognizing Chinese IR Theory," in Asian Thought on China's Changing International Relations, ed. Niv Horesh and Emilian Kavalski, (Basingstoke: Palgrave, 2014), 230-48.

${ }^{89}$ J. Samuel Barkin, Realist Constructivism: Rethinking International Relations Theory (Cambridge: Cambridge University Press, 2010).

${ }_{90}$ Yee-Kuang Heng, "Ghosts in the Machine: Is IR Eternally Haunted by the Spectre of Old Concepts," International Relations 47, no. 5 (2010): 535-56.

${ }_{91}$ Coles, Visionary Pragmatism, 53. 
Cultural Interpersonal Communication, edited by Stella Ting-Toomey and Felipe Corzenny, 28-57. London: Sage, 1991.

Chen, Ching-Chang. "The Absence of Non-Western IR Theory in Asia Reconsidered." International Relations of the Asia-Pacific 11, no. 1 (2011): 1-23.

Chong, Melody P.M., Ping Ping Fu, and Yu Fan Shang. "Relational Power and Influence Strategies: A Step Further in Understanding Power Dynamics." Chinese Management Studies 7, no. 1 (2013): 53-73.

Chow, Rey. "Violence in the Other Country: China as Crisis, Spectacle, and Woman." In Third World Women and the Politics of Feminism, edited by Ann Russo, Lourdes Torres, and Chandra Talpade Monaty, 80-100. Bloomington, IN: Indiana University Press, 1991.

Chowdhry, C. and S.M. Rai. "The Geographies of Exclusion and the Politics of Exclusion: Race-based Exclusions in the Teaching of International Relations.” International Studies Perspectives 10, no. 1 (2009): 84-91.

Coles, Romand. Visionary Pragmatism. Durham, NC: Duke University Press, 2016.

Contessi, Nicola P. "Foreign and Security Policy Diversification in Eurasia: Issue Splitting, Co-alignment, and Relational Power.” Problems of Post-Communism 62, no. 5 (2015): 299-315.

DeGlopper, Donald R. Lukang: Commerce and Community in a Chinese City. Albany, NY: SUNY Press, 1995.

Farh, Jiing-Lih, Anne S. Tsui, Katherine Xin, and Bor-Shiuan Cheng. "The Influence of Relational Demography and Guanxi: The Chinese Case.” Organization Science 9, no. 4 (1998): 471-88.

Foucault, Michel. The Order of Things: An Archaeology of the Human Sciences. London: Routledge, 2002.

Gao, Yanli. "China's World View and World Historical Studies." Dimensioni e problemi della ricerca storica 20, no. 1(2008): 255-68.

Gilpin, Robert. War and Change in World Politics. Cambridge: Cambridge University Press, 1981.

Gold, Thomas, Dong Ghine, and David L. Wank. Social Connections in China: Institutions, Culture, and the Nature of Guanxi. Cambridge: Cambridge University Press, 2002.

Hammond, Scott C., and Lowell M. Glenn. "The Ancient Practice of Chinese Social Networking: Guanxi and Social Network Theory." E:CO 6, no. 1/2 (2004): 24-31.

Heffner, Lanette. Inside the Dragon's Briefcase: China's Emergent Economy. San Antonio, TX: University of Texas, 2008.

Heng, Yee-Kuang. "Ghosts in the Machine: Is IR Eternally Haunted by the Spectre of Old Concepts." International Relations 47, no. 5 (2010): 535-56.

Ho, David Y.F. “On the Concept of Face.” American Journal of Sociology 81, no. 4 (1976): 867-84.

—. "Selfhood and Identity in Confucianism, Taoism, Buddhism, and Hinduism: Contrasts with the West." Journal of the Theory of Social Behaviour 25, no. 2 (1995): 115-39.

Hückel, Bettina. "Theory of International Relations with Chinese Characteristics: The Tianxia System from a Metatheoretical Perspective.” Diskurs 8, no. 2 (2012): 34-64.

Hwang, Kwang-kuo. "Face and Favour: The Chinese Power Game.” American Journal of Sociology 92, no. 4 (1987): 944-74.

Jia, Wenshan. "An Intercultural Communication Model of International Relations: The Case of China." In Challenges to Chinese Foreign Policy: Diplomacy, Globalization, and the Next World Power, edited by Yufan Hao, C.X. George Wei, and Lowell Dittmer, 319-34. Lexington, KY: University Press of Kentucky, 2009.

—. "The Wei (Positioning)-Ming (Naming)-Lianmian (Face)-Guanxi (Relationship)-Renqing (Humanized Feelings)-Complex in Contemporary Chinese Culture.” In Confucian Cultures of Authority, edited by Peter H. Hershock and Roger T. Ames, 49-64. Albany, NY: SUNY Press, 2006.

Kavalski, Emilian. Central Asia and the Rise of Normative Powers: Contextualzing the Security Governance of the European Union, China, and India. New York: Bloomsbury, 2012.

- The Guanxi of Relational International Theory. London: Routledge, 2017.

"More of the Same: An Unpredictable Trump Foreign Policy in an Unpredictable Central Asia." Monde Chinois 4, no. 48 (2016): 112-17. 
. "Recognizing Chinese IR Theory". In Asian Thought on China's Changing International Relations, edited by Niv Horesh and Emilian Kavalski, 230-48. Basingstoke: Palgrave, 2014.

_. "Relationality and Its Chinese Characteristics." China Quarterly 226 (2016): 551-9.

. "Shanghaied into Cooperation: Framing China's Socialization of Central Asia." Journal of Asian and African Studies 45, no. 2 (2010): 131-45.

- "The Struggle for Recognition of Normative Powers: Normative Power Europe and Normative Power China in Context." Cooperation and Conflict 48, no. 2 (2013): 247-67.

. "Timescapes of Security: Clocks, Clouds, and the Complexity of Security Governance." World Futures 65, no. 7 (2009): 527-51.

"Whether Power Transition and Whither If One". In Power Transition in Asia, edited by David Walton and Emilian Kavalski, 207-21. London: Routledge, 2017.

- World Politics at the Edge of Chaos: Reflections on Complexity and Global Life. Albany, NY: State University of New York Press, 2015.

Kavalski, Emilian, and Young Chul Cho. "Governing Uncertainty in Turbulent Times." Comparative Sociology 14, no. 3 (2015): 429-44.

Kowalzig, Barbara. "Performances of Theoria in Their Sacred and Political Context." In Pilgrimage in GraecoRoman and Early Christian Antiquity, edited by Jas Elsner and Ian Rutherford, 41-72. Oxford: Oxford University Press, 2005.

King, Ambrose Y.C. "The Individual and Group in Confucianism: A Relational Perspective.” In Individualism and Holism: Studies in Confucian and Taoist Values, edited by Donald J. Munro, 57-72. Ann Arbor, MI: University of Michigan Press, 1985.

Langenberg, Eike A. Guanxi and Business Strategy. New York: Springer, 2007.

Ledeneva, Alena. “'Blat' and 'Guanxi': Informal Practices in Russia and China." Comparative Studies in Society and History 50, no. 1 (2008): 118-44.

Lee, Don Y., and Philip L. Dawes. "Guanxi, Trust, and Long-Term Orientation in Chinese Business Markets." Journal of International Marketing 13, no. 2 (2005): 28-56.

Ling, LH.M. The Dao of World Politics. London: Routledge, 2015.

Liu, Jee Loo. "Reconstructing Chinese Metaphysics: A White Paper.” Journal of East-West Thought 1, no. 2 (2011): 1-13.

Liu, Qing. "From 'all under heaven' to Critical Cosmopolitanism: The Transformation of China's World Consciousness." In Shared Values in a World of Cultural Pluralism, edited by Candido Mendes, 119-48. Rio de Janeiro: Academy of Latinity, 2014.

Luo, Yadong. "Guanxi: Principles, Philosophies, and Implications.” Human Systems Management 16, no. 1 (1997): 43-51.

Nightingale, Andrea Wilson. Spectacles of Truth in Classical Greek Philosophy: Theoria in Its Cultural Context. Cambridge: Cambridge University Press, 2004.

Nordin, Astrid. "Hegemony in Chinese? Ba in Chinese International Relations." In Politics of the 'Other' in India and China, edited by Lion König and Bidisha Chaudhuri. London: Routledge, forthcoming.

Paltiel, Jeremy. “China’s Regionalization Policies: Illieral Internationalism or Neo-Mencian Benevolence.” In China and the Global Politics of Regionalization, edited by Emilian Kavalski, 47-62. Abingdon: Routledge, 2009.

Parks, Malcolm R. "Ideology of Interpersonal Communication: Off the Couch and Into the World.” In Communication Yearbook, edited by Michael Burgon, 79-107. New Brunswick, NJ: Transaction Publishers, 1982.

Pye, Lucian W. Chinese Commercial Negotiating Style. Cambridge, MA: Oelgeschlager, Guun, and Hain, 1982.

_. "Factions and the Politics of Guanxi: Paradoxes in Chinese Administrative and Political Behaviour." The China Journal 34, no. 2 (1995): 35-53.

. The Spirit of Chinese Politics: A Psychocultural Study of the Authority Crisis in Political Development. Cambridge, MA: MIT Press, 1968. 
Qin, Yaqing. "Relationality and Processual Construction: Bringing Chinese Ideas into International Relations Theory.” Social Sciences in China 30, no. 3 (2009): 5-20.

—. "Why Is There No Chinese International Theory." International Relations of the Asia-Pacific 7, no. 3 (2007): 313-40.

Risse, Thomas. “'Let's Argue': Communicative Action in World Politics.” International Organization 54, no. 1 (2000): 1-39.

Rosemont, Henry. “Two Loci of Authority: Autonomous Individuals and Related Persons." In Confucian Cultures of Authority, edited by P.H. Hershock and R.T. Ames, 1-20. Albany, NY: SUNY Press, 2006.

Russell, Roberto, and Juan Gabriel Tokatlian. "From Antagonistic Autonomy to Relational Autonomy: A Theoretical Reflection from the Southern Cone.” Latin American Politics and Society 45, no. 1 (2003): 1-24.

Schwartz, Benjamin I. “The Maoist Image of World Order.” Journal of International Affairs 21, no. 1 (1967): 92102.

Shih, Chih-yu. "Transcending Hegemonic International Relations Theorization: Nothingness, Re-Worlding, and Balance of Relationship." All Azimuth 6, no. 2 (2017): 19-42.

Shimizu, Kosuke. "Materializing the Non-Western." Cambridge Review of International Affairs 28, no. 1 (2015): 3-20.

Swain, Margaret Byrne. Chinese Cosmopolitanism [Tianxia He Shijiie Zhuyi]. In Cultural Heritage Politics in China, edited by Tami Blumenfield and Helaine Silverman, 33-50. New York: Springer, 2013.

Tong, Shijun. “Chinese Thought and Dialogical Universalism.” In Europe and Asia beyond East and West, edited by Gerard Delanty, 305-15. London: Routledge, 2006.

Tsui, Anne S., and Jiing-Lih Larry Farh. "Where Guanxi Matters: Relational Demography and Guanxi in the Chinese Context.” Work and Occupations 24, no. 1 (1997): 56-79.

Tu, Wei-ming. Confucian Thought: Selfhood as Creative Transformation. Albany, NY: SUNY Press, 1985.

Uemura, Takeshi. "Understanding Chinese Foreign Relations: A Cultural Constructivist Approach." International Studies Perspectives 16, no. 3 (2015): 345-65.

Vucetic, Srdjan. The Anglosphere: A Genealogy of Racialized Identity in International Relations. Stanford, CA: Stanford University Press, 2011.

Wen, Haiming, and Wang Hang. "Confucian Cultural Psychology and Its Contextually Creative Intentionality." Culture \& Psychology 19, no. 2 (2013): 184-202.

Wolfers, Arnold. Discord and Collaboration. Baltimore, NJ: The John Hopkins University Press, 1962.

Womack, Brantly. "China as a Normative Foreign Policy Actor." In Who is a Normative Foreign Policy Actor?, edited by Nathalie Tocci, 265-98. Brussels: Center for European Policy Studies, 2008.

Yang, K.S., and David Y.F. Ho. “The Role of Yuan in Chinese Social Life: A Conceptual and Empirical Analysis.” In Asian Contributions to Psychology, edited by Anand C. Paranjpe, David Y.F. Ho, and Robert W. Rieber, 263-81. New York: Praeger, 1988.

Yang, Mayfair Mei-hui. Gifts, Favors, and Banquets: The Art of Social Relationships in China. Ithaca, NY: Cornell University Press, 1994.

- "The Resilience of Guanxi and Its New Deployments: A Critique of Sone New Guanxi Scholarship." The China Quarterly 42, no. 170 (2002): 459-76.

Yeung, Irene Y.M., and Rosalie L. Tung. "Achieving Success in Confucian Societies: The Importance of Guanxi (Connections).” Organizational Dynamics 25, no. 2 (1996): 54-65.

Yue, Ricky Wai-kay. "Beyond Dependency: The Promise of Confucianism in Post-Westphalia International Relations." Bandung: Journal of the Global South 2, no. 4 (2015): 1-17.

Zhang, Feng. "Confucian Foreign Policy Traditions in Chinese History." The Chinese Journal of International Politics 8, no. 2 (2015): 197-218. 